\title{
The Principal's Leadership in Implementing the Full-Day Kindergarten: A Literature Review
}

\author{
Nanik Lestari ${ }^{1}$, Dini Cahyati ${ }^{2}$ \\ ${ }^{1,2}$ Student of Education Administration, Universitas Lampung, Bandar Lampung, Indonesia
}

\begin{abstract}
The importance of the principal's leadership in implementing the full-day kindergarten education program attracted authors to research and this article discusses the results of the literature review conducted by the authors. There are a number of articles about the principal's leadership review and full-day kindergarten implementation especially in the context of the world that can be found. The purpose of this review is to find out the principal's leadership in implementing full-day kindergarten in a world context. Based on the results of literature reviews from various countries in the world, the authors found the scope of the articles reviewed is still very limited and it is very difficult to get literature that combines the two variables, therefore, the authors would be positively explain the findings for each variable. The results of the review literature on school principal's leadership show that the principal's leadership in carrying out his role as a leader has an impact on teacher performance and student achievement. The results of the review literature on the implementation of a full day kindergarten show that children who attend kindergarten (FDK) a full day experience academic and development benefits compared to children who attend a half-day program. Thus, the authors are interested in following up related to the principal's leadership in implementing full-day kindergarten.
\end{abstract}

KEYWORDS: Leadership, Principal’s Leadership, Implementing, Full Day Kindergarten, Kindergarten.

\section{INTRODUCTION}

Learning activities in kindergartens occur in the process of participation, students learn through their environment both indoors and outdoors (Shoval, Sharir, Arnon, \& Tenenbaum, 2018). Full-day kindergarten is one way to increase stimulus for children's academic skills, especially for students who are at risk of experiencing academic difficulties (Thompson \& Sonnenschein, 2016). The fullday kindergarten program can benefit children, with regard to the child's holistic development, transition in the primary classroom and academic development. This full-day program provides universal opportunities for students and families to access quality early learning environments (Langford, Di Santo, Valeo, Underwood, \& Lenis, 2018)

The beginning of era full-day kindergarten education system today is actually marked by the number of favorite and excellent labeled schools. Quality improvement. It is known that the term Full-day school according to Hirsch, B. J is only used in Indonesia, in other countries they refer to the After-School Program (Hannum \& Park, 2004). The authors of this article focus on using the term full-day used in Indonesia.

In this regard, it has been known that several studies have examined full-day kindergarten in various countries such as the United States (M. A. Gottfried, 2017) (M. A. Gottfried \& Le, 2017), (Ansari \& Purtell, 2017), Kanada (Heagle, Timmons, Hargreaves, \& Pelletier, 2017), (Underwood, Di Santo, Valeo, \& Langford, 2016), (Brownell et al., 2015), English. (Heydon, Moffatt, \& Iannacci, 2015),Indonesia (Hakim \& Parameswari, 2015).

The Kindergarten full-day program is an educational program that provides a minimum of 6 hours a day starting at 8:00 AM to 3:00 PM. The research found that children who attend full-day kindergarten have readiness to attend primary school, and have the ability to read when compared to children who take half-day programs. Children on full-day have advantages and readiness to learn because according to the results of research teachers have more time to be able to identify children's learning styles, children's needs and problems faced by children. While from the perspective of their children more have the choice to do various activities, learning choices and deepen the material because of more time. In 1998-1999 in America began to develop full-day kindergarten schools, even $61 \%$ of Kindergarten institutions have provided full-day services, it is different from in Indonesia because the concept of PAUD Full-day only developed in 2010, even today the implementation of Full-PAUD day could not yet be identified and recorded by the government to find out the exact number of institutions that hold PAUD Full-day (Fauziah \& Sugito, 2016). 


\section{International Journal of Current Science Research and Review}

ISSN: 2581-8341

Volume 04 Issue 03 March 2021

DOI: 10.47191/ijesrr/V4-i3-04, Impact Factor: 5.825

IJCSRR@ 2021

WwW.ijcsrr.org

Kindergarten full-day emerges as one of the educational systems that has a child-centered learning process. Where the learning process does not only emphasize learning on the cognitive aspects, but in the learning system there are various kinds of creative learning methods not based on the amount of information knowledge delivered by the teacher alone but how children learn in "how to learn", "how to do ", and" how to feel ". This is consistent with the opinion of Johnson et al that the educational aspect has important consequences in a child's life, the level of education of a child provides clear benefits for the child and his school (Hannum \& Park, 2004). The realization of these educational goals is highly dependent on the leadership skills and wisdom of the principal who is one of the educational leaders. Because the principal as a professional official in the school organization. Based on the description above, it is necessary to know more about "How is the Principal's Leadership in Implementing Full-Day Kindergarten in a World Context"?

\section{LITERATUR RIVIEW}

\section{A. Principal's Leadership}

Leadership according to Heifetz is a social activity (Aravena, 2019). The principal is the person who has the highest authority in the school because the principal is responsible for all school activities and plays an important role in improving the quality of education and plays an important role in supporting the academic and social success of all students, especially students who have traditionally been marginalized because of race, ethnicity, language, ability, socioeconomic status, gender, and religion (Brooks \& Brooks, 2019), (Truong, Hallinger, \& Sanga, 2017), (Eisenschmidt, Kuusisto, Poom-Valickis, \& Tirri, 2019).

The conditions that must be met by a leader in order to succeed in leading an organization effectively are as follows: a) Having high enough intelligence to be able to think and seek to resolve any problems that arise appropriately and wisely b) Have stable or uneasy emotions oscillated by various changes in atmosphere and can separate between personal problems, household problems, with organizational problems c) Having intelligence in dealing with others and being able to make subordinates feel at home, happy, and satisfied at work d) Having expertise to organize and move the subordinate wisely in realizing the goals of the organization and to know precisely when and to whom responsibility and authority will be delegated. The principal is someone who determines the central point and rhythm of a school. Because schools are complex institutions, schools as organizations need coordination. The success of the school is the success of the principal too. Principals succeed if they understand the existence of the school as a complex and unique organization, and are able to carry out the role of the principal as someone who is given the responsibility to lead the school. Based on the formulation above shows how important the principal's role is in driving school life to achieve goals. There are two things that need to be considered in the formulation as follows: a) The principal acts as a central force which is the driving force of school life b) Principals must understand their duties and functions for the success of the school, and have a concern for staff and students (Setiyati, 2014)

School leadership has a significant effect on the features of school organs, which positively influences the quality of teaching and learning. The function of leadership is to build organizational conditions that foster high quality teaching and produce improvement in learning outcomes (Leithwood, Harris, \& Hopkins, 2019).

Functionally education plays a very important role in the development of people and the nation, therefore an educational institution is demanded to be able to carry out the school management functions properly. One of them is through the principal's management strategy. Robbin argues that, leadership is the ability to influence a group toward the achievement goals. One of the functions of leadership is to influence a person / group in order to achieve a desired target, therefore the leadership process must be carried out in order to coordinate and direct both individuals and groups to achieve a predetermined goal, so that a leader needs a style and certain types in order to facilitate and smooth the rare and leadership processes. The principal's leadership management strategy must be constructed based on changes and developments in the community environment while still considering aspects of togetherness and diversity, so as to be able to hold new programs that are able to improve the quality of education and education staff and must always be evaluated and even updated. Most management of school principals (public schools) tend to be administrative and merely implement policies from the top down without considering improvement and development projects that should always be the main agenda for a leader. therefore the guidance done by a school principal should not only be administrative but rather on the development and improvement of the quality of educational competencies and education personnel (Muflikha \& Haryanto, 2019). 


\section{International Journal of Current Science Research and Review}

ISSN: 2581-8341

Volume 04 Issue 03 March 2021

DOI: 10.47191/ijesrr/V4-i3-04, Impact Factor: 5.825

IJCSRR@ 2021

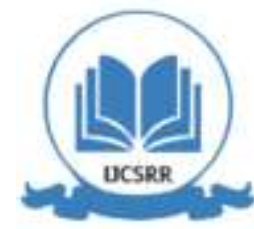

WwW.ijcsrr.org

Leadership style is a picture of the behavior of a leader in an effort to influence the activities or activities carried out by his subordinates in order to achieve organizational goals. Lots of types / types of leadership styles that are developing at this time used by the leader. This leadership style in turn turns out to be the basis in discriminating or clarifying the types of leadership. Effective leadership has the characteristics of (1) being flexible, choosing his actions from the range of leader behavior, (2) aware of his self, group and situation. From all that considered to choose a certain leadership style. (3) Inform subordinates of their influence on each issue and how the leader will use his authority. (4) Using general supervisors, subordinates work on their own daily work provinces and make decisions about work within specified limits. (5) Always remember, both urgent issues and the long-term effectiveness of individuals and groups before acting (7) always easy to find if subordinates want to simulate problems and show their interests and ideas, (8) Keep promises given to subordinates, quickly handle complaints and give answers earnestly and not convoluted. (9) Give instructions on adequate work methods, increase security and avoid mistakes, by reminding workers' level of experience. Explain the reasons why it is given. Thus the appropriate leadership style used is a leadership style that is task oriented and subordinate oriented. The task-oriented style pays more attention to the completion of tasks with very strict supervision so that the task is completed according to his wishes. Good relations with their subordinates are ignored, as long as the subordinates must work hard, be productive and be punctual. Husaini Usman said that the relationship-oriented / subordinate style tends to pay more attention to good relations with his subordinates, to motivate his employees rather than to supervise closely, and more importantly to feel his subordinates more(Marlina, 2020)

There are two dimensions of leadership style in educational and non-educational settings, namely: (a) leadership style that is work or task oriented, and (b) leadership style that is oriented towards human relations. And in general there are two main attitudes of one's leadership, namely: (a) leadership oriented to tasks or concern for production, (b) leaders oriented to human aspects or concern for people. Stoner in Harbani Pasolong argues that there are two styles of leadership, namely: (a) task-oriented style, (b) employeeoriented style (Gusman, 2020)

The principal is the highest leader in the school. The pattern of leadership will be very influential even very determining on the progress of the school. Therefore, in modern education, the principal's leadership needs to get serious attention. The success of an educational institution depends very much on the leadership of the principal. Because he as a leader in his institution, he must be able to bring his institution towards the achievement of the goals set, he must be able to see a change and be able to see the future in a better globalization life (Hadi, 2020)

Principal's leadership is very important for the success of school organizations because leaders create positive changes in education by encouraging existing staff in schools to take initiative and change (Quin, Deris, Bischoff, \& Johnson, 2015). Potential learners can be influenced by the leadership of the school principal in various ways through instructional and non-instructional tasks, the level and way of leadership of the school affect student learning outcomes depending on certain behaviors and the overall school environment features of the principal, teachers, students and community context (Urick, 2016).

The role of the principal is very important in transforming the educational process, student performance and learning outcomes because the quality of school leaders is related to the academic success of students; therefore, schools must invest in the training and leadership development of principals (Jones et al., 2015), (Tingle, Corrales, \& Peters, 2019). In short, the principal plays a key role in this domain by shaping the school environment, motivating and supporting continuous learning in school staff (Lijuan, Hallinger, \& Ko, 2016). Three types of principals' leader's profile were identified: "profiles that think of people", "profiles of administrative minds" and "profiles of moderate minds" (Dou, Devos, \& Valcke, 2017).

\section{B. Full Day Kindergarten}

Kindergarten is an important transition point for students because children leave the learning environment early and enter the K-12 system with a variety of backgrounds, experiences, and skills (Joseph et al., 2019). Kindergarten is a form of early childhood education unit in the formal education pathway that organizes educational programs for children aged four years to six years whose role is to stimulate the growth and development of children both physically and spiritually (Pyle, Prioletta, \& Poliszczuk, 2018). Kindergarten students are at a critical time for development, the future success of schools is largely determined by one's ability to transition to a full-day school environment (Heagle et al., 2017)

Full-day kindergarten is one of the education that has been used to try to improve the academic skills of students from an early age, especially those who are experiencing academic difficulties (Thompson \& Sonnenschein, 2016). The Full-day Kindergarten Program provides a program with a pedagogical approach as well as a curriculum that is planned and delivered by educators using 


\section{International Journal of Current Science Research and Review}

ISSN: 2581-8341

Volume 04 Issue 03 March 2021

DOI: 10.47191/ijcsrr/V4-i3-04, Impact Factor: 5.825

IJCSRR@ 2021

www.ijcsrr.org

space and resources (Timmons, 2018). Kindergarten full-day programs can benefit children in connection with the holistic development of children, academic development with better academic results and promotion of SR. In addition this program provides universal opportunities for children and families to access quality early learning environments (Youmans, Kirby, \& Freeman, 2018), (Coughenour, Pharr, Gakh, Clark, \& Cheong, 2019).

Fullday school is a public school model that integrates the teaching system intensively by giving additional time specifically for the deepening of children, entering at 07.00 and returning at 14:30. Schools with this model are very popular with modern people who have a very busy schedule outside the home(Brianti, Karini, \& Agustin, 2010).

Some reasons why the full-day kindergarten system will be officially applied in Indonesian education. In addition to minimizing the negative impacts caused by the school environment, through this program the activities of students can be well directed. Furthermore, Elicker and Mathur have found a positive effect that children who attend school in the full-day kindergarten program are considered to have a more positive impact and a better level of development achievement than children in half-day programs (Arifin \& Zahro, 2018).

Full day kindergarten was established to answer various problems that exist in the community, the community expects their children to get good academic and non-academic education and avoid free promiscuity. Full day kindergarten was established because the community environment is not good, parents lack time in supervising children because of work and children tend to prefer playing rather than studying after they come home from school. Full day school was established due to several reasons including, firstly the lack of parents' time at home due to work demands, this is intended so that children do not fall into negative things, secondly because of the need for supervision of children's safety while parents are working, thirdly because the need for additional religious studies because of the lack of parental time for children, and fourth, namely the need for improvement in the quality of education. Schools with a full day school system are schools that implement a full day learning system, meaning that students learn from morning to evening or afternoon. Full day school is a school that applies the same curriculum as schools in general, namely the Ministry of National Education curriculum. Full day school is considered to be able to balance academic knowledge with religious knowledge, with the existence of a full day school system that is expected to improve the academic capacity of students in preparation for the next level. Learning with a full day school system will run well if supported by several factors, as quoted from research, schools with a full day school system must have a good schedule setting, the learning process must have a good strategy and schools must have facilities that can support learning process and deepening of the material. Because in general students will easily feel bored if they study all day at school. The learning process in a full day school system such as school work can be done by students through the guidance of subject teachers while at school, but this does not mean that the school restricts students from continuing to learn but in full day school learning methods and media are applied fun learning so students will not feel bored at school, a teacher must be able to innovate and be creative so that the learning process can go well (Irayasa et al., 2019).

\section{RESEARCH METHODOLOGY}

This research can be categorized as a literature review research. The purpose of conducting a literature review is to obtain a theoretical foundation that can support the solution of the problem being studied. The review process begins with a search engine, google cendikia, to search for articles with keywords. Principal's leadership and Full-day kindergarten. Searches ranged from 20152020 and identified a total of 200 studies and articles. The criteria for inclusion in this study are as follows:
a. Qualitative results from principals' leadership in implementing full day kindergarten.
b. Research carried out in the world
c. This research uses English
d. Dissertations and theses are excluded.

Steps in the Literature Review of each of the principals' leadership variables and the fullergarten kindergarten include: Step 1: Formulate the Problem

- Choose a topic that fits the issue and interest.

- The problem must be written completely and accurately

Step 2: Look for Literature

- Look for literature relevant to research 


\section{International Journal of Current Science Research and Review}

ISSN: 2581-8341

Volume 04 Issue 03 March 2021

DOI: 10.47191/ijesrr/V4-i3-04, Impact Factor: 5.825

IJCSRR@ 2021

- Get an overview of the research topic

- Research sources are very helpful if supported by knowledge of the topic being studied.

- These sources provide an overview / summary of previous research.

Step 3: Evaluate Data

- Look at any contribution to the topic discussed

- Search and find the right data source as needed to support research

- It can be in the form of qualitative data, quantitative data or data derived from a combination of both

Step 4: Analysis and Interpretation

- Discuss and find and summarize literature.

\section{RESULTS AND DISCUSSION}

This section reports the main findings reviewed from several articles the author has read. The analysis selects most of the articles based on the principal's leadership in implementing full-day kindergarten education. The articles reviewed are research conducted in several countries in the world. The table describes the results of the literature review conducted by the author. Research has been carried out in several schools and universities.

\begin{tabular}{|c|c|c|c|c|c|}
\hline $\begin{array}{l}\text { Author and } \\
\text { Year }\end{array}$ & Title & Country & Method & Sample & Result \\
\hline $\begin{array}{l}\text { Ansari and } \\
\text { Purtell (2017) }\end{array}$ & $\begin{array}{l}\text { Activity settings in } \\
\text { full-day } \\
\text { kindergarten } \\
\text { classrooms and } \\
\text { children's early } \\
\text { learning. Early } \\
\text { Childhood Research } \\
\text { Quarterly, }\end{array}$ & $\begin{array}{l}\text { United } \\
\text { states }\end{array}$ & Qualitative & $\begin{array}{l}0.620 \\
\text { Children }\end{array}$ & $\begin{array}{l}\text { The results show that, the average } \\
\text { kindergarten child does group activities } \\
\text { spend about } 34 \% \text { every day } \\
\text { However, a difference was found in } \\
\text { children's experiences when learning a } \\
\text { day throughout the nation. }\end{array}$ \\
\hline $\begin{array}{l}\text { Felipe Aravena, } \\
(2017)\end{array}$ & $\begin{array}{l}\text { Destructive } \\
\text { Leadership } \\
\text { Behavior: An } \\
\text { Exploration Study in } \\
\text { Chile }\end{array}$ & Chile & $\begin{array}{l}\text { Qualitative } \\
\text { research } \\
\text { based on } \\
\text { phenomenon } \\
\text { of } \\
\text { interpretati- } \\
\text { on }\end{array}$ & $\begin{array}{l}207 \quad(34 \%) \\
\text { Teachers }\end{array}$ & $\begin{array}{l}\text { Leaders who are often labeled as } \\
\text { destructive show autocratic leadership, } \\
\text { poor communication, inconsistent } \\
\text { erratic behavior, and poor strategic } \\
\text { skills. }\end{array}$ \\
\hline $\begin{array}{ll}\text { Melanie } & \text { C. } \\
\text { Brooks } & \& \\
\text { Jeffrey } & \text { S. } \\
\text { Brooks (2018) }\end{array}$ & $\begin{array}{l}\text { Culturally } \\
\text { (ir)relevant school } \\
\text { leadership: } \\
\text { Ethnoreligious } \\
\text { conflict and school } \\
\text { administration in the } \\
\text { Philippines }\end{array}$ & $\begin{array}{l}\text { Philippin } \\
\text { es }\end{array}$ & Qualitative & 42 Principals & $\begin{array}{l}\text { The principal in Northern Mindanao is } \\
\text { a leader that is not culturally relevant. } \\
\text { They perpetuate the status quo of } \\
\text { marginalization of students from } \\
\text { various backgrounds. As a result, some } \\
\text { students receive the opportunity to get a } \\
\text { quality education while others do not. }\end{array}$ \\
\hline $\begin{array}{l}\text { Eve } \\
\text { Eisenschmidt, } \\
\text { Elina Kuusisto, } \\
\text { Katrin Poom- } \\
\text { Valickis \& Kirsi } \\
\text { Tirri (2019) }\end{array}$ & $\begin{array}{l}\text { Virtues that create } \\
\text { purpose for ethical } \\
\text { leadership: } \\
\text { Exemplary } \\
\text { principals from } \\
\text { Estonia and Finland }\end{array}$ & Australia & Qualitative & ------- & $\begin{array}{l}\text { The principal at Northern Mindanao is } \\
\text { a leader that is not culturally relevant. } \\
\text { They perpetuate the status quo of } \\
\text { marginalization of students from } \\
\text { various backgrounds. As a result, some } \\
\text { students receive the opportunity to get a } \\
\text { quality education while others do not. }\end{array}$ \\
\hline
\end{tabular}




\section{International Journal of Current Science Research and Review}

ISSN: 2581-8341

Volume 04 Issue 03 March 2021

DOI: 10.47191/ijesrr/V4-i3-04, Impact Factor: 5.825

IJCSRR@ 2021

www.ijcsrr.org

\begin{tabular}{lllll}
\hline $\begin{array}{l}\text { Author and } \\
\text { Year }\end{array}$ & Title Country & Method & Sample & Result \\
\hline Courtney A Qualitative Study & $\begin{array}{l}\text { Southern } \\
\text { Coughenour, Qualitative }\end{array}$ & & Children who attend the day-to-day \\
Jennifer Pharr, Community & kindergarten (FDK) experience greater \\
Maxim Gakh, Stakeholder Views & & ----- & academic and developmental benefits \\
Sheila Clark and & of the Link between & & compared to the children attending the \\
Prescott Cheong & Full-Day program. \\
(2019) & $\begin{array}{l}\text { Kindergarten and } \\
\text { Health in Southern }\end{array}$ & & \\
Nevada &
\end{tabular}

Diya Dou, Geert The relationships

Devos and between school

Martin Valcke autonomy gap,

(2017) principal leadership, teachers job satisfaction and organizational commitment

Eve

Eisenschmidt, Virtues That Create

Elina Kuusisto, Katrin PoomValickis \& Kirsi Tirri (2019) Purpose For Ethical

Finland Qualitative Leadership: Exemplary Principals From Estonia And Finland
China Qualitative 48 Principals

Quative

Significant instructional and transformational leadership on teacher job satisfaction and organizational commitment, mediated by the indirect impacts of the school and teacher climate Self-efficacy. The school autonomy gap, which is closely related to the leadership of the school principal, appears as important influence in the path model

This critical incident relates to the principal's own self as a principle and to the principal's work with teachers, students and families, and their community as a whole, Principals demonstrate virtue of wisdom and knowledge in creating long-term provisions for their schools and building schools for future generations.

\begin{tabular}{|c|c|c|c|c|c|}
\hline $\begin{array}{l}\text { Michael } \\
\text { Gottfried }\end{array}$ & A. & $\begin{array}{l}\text { Does Absenteeism } \\
\text { Differ for Children } \\
\text { with Disabilities in } \\
\text { Full-Day versus } \\
\text { Part-Day } \\
\text { Kindergarten }\end{array}$ & $\begin{array}{l}\text { United } \\
\text { States }\end{array}$ & Longitudinal & $\begin{array}{l}2.140 \\
\text { Children } \\
\text { Kinderga }\end{array}$ \\
\hline $\begin{array}{l}\text { Michael } \\
\text { Gottfrie, } \\
\text { ViNhuanL }\end{array}$ & & $\begin{array}{l}\text { Is full-day } \\
\text { kindergarten linked } \\
\text { to children's } \\
\text { physical activity }\end{array}$ & $\begin{array}{l}\text { United } \\
\text { Stated }\end{array}$ & Longitudinal & $\begin{array}{l}14.370 \\
\text { students }\end{array}$ \\
\hline
\end{tabular}

In both models, children with disabilities in FDK have more days absent than children with disabilities in PDK. 


\section{International Journal of Current Science Research and Review}

ISSN: 2581-8341

Volume 04 Issue 03 March 2021

DOI: 10.47191/ijesrr/V4-i3-04, Impact Factor: 5.825

IJCSRR@ 2021

www.ijcsrr.org

\begin{tabular}{|c|c|c|c|c|c|}
\hline $\begin{array}{l}\text { Author and } \\
\text { Year }\end{array}$ & Title & Country & Method & Sample & Result \\
\hline $\begin{array}{l}\text { Kaitlyn Heagle, } \\
\text { Kristy } \\
\text { Timmons, } \\
\text { Fabienne } \\
\text { Hargreaves \& } \\
\text { Janette Pelletier } \\
\text { (2017) }\end{array}$ & $\begin{array}{l}\text { The Social } \\
\text { Kindergartener: } \\
\text { Comparing } \\
\text { Children's } \\
\text { perspectives Of } \\
\text { Full- And Half-Day } \\
\text { Kindergarten }\end{array}$ & Canada & Longitudinal & $\begin{array}{l}\text { The sample } \\
\text { consisted of } \\
306 \text { full-day } \\
\text { kindergarten } \\
\text { children } \\
\text { (mean age = } \\
63 \\
\text { month) and } \\
251 \\
\text { kindergarten } \\
\text { children half a } \\
\text { day (mean } \\
\text { age = } 61 \\
\text { months }\end{array}$ & $\begin{array}{l}\text { No significant differences were found } \\
\text { in children's reports their favorite thing } \\
\text { about school, shows that regardless of } \\
\text { Programs, children most enjoy playing } \\
\text { and social activities. This The findings } \\
\text { reinforce the importance of } \\
\text { kindergarten based full-day play } \\
\text { program }\end{array}$ \\
\hline
\end{tabular}

Michelle Jones,

Donnie Adams,

Mabel Tan

Hwee Joo, Vasu

Muniandy,Corin

ne Jacqueline

Perera \& Alma

Harris (2015)

Gail Joseph

Janet

S. Reliability

of

Soderberg, Sara

Washington State's

Stull, Kevin

Kindergarten Entry

Cummings,

Assessment

Deborah

McCutchen \&

Rachel J. Han

(2019)
Youmans, Kirby and Freeman

(2017)

How effectively Canada Qualitative does the full-day,

play-based

kindergarten

programme in

Ontario promote

self-regulation,

literacy, and

numeracy

Angela Urick Examining

(2015)

Principal perception States

Qualitative
United Qualitative

54 Teachers

Malaysia Qualitative

States

213 FDELK schools with 6453 FDELK students and 732 nonFDELK schools
This article proposes that despite pressure on them to secure better school and student outcomes, principals in Malaysia increasingly see their leadership practices as transformational and distributed.

Reliability among assessors varies by developmental domain and is weaker for dual language learners and children with developmental delays.

8,524

Appropriate improvement in leadership Principal of style practice by shared instructional

There is no benefit for students participating in the FDELK program when compared to peers in the Half Day Kindergarten (HDK) program or the International Day Kindergarten program. 


\section{International Journal of Current Science Research and Review}

ISSN: 2581-8341

Volume 04 Issue 03 March 2021

DOI: 10.47191/ijcsrr/V4-i3-04, Impact Factor: 5.825

IJCSRR@ 2021

www.ijcsrr.org

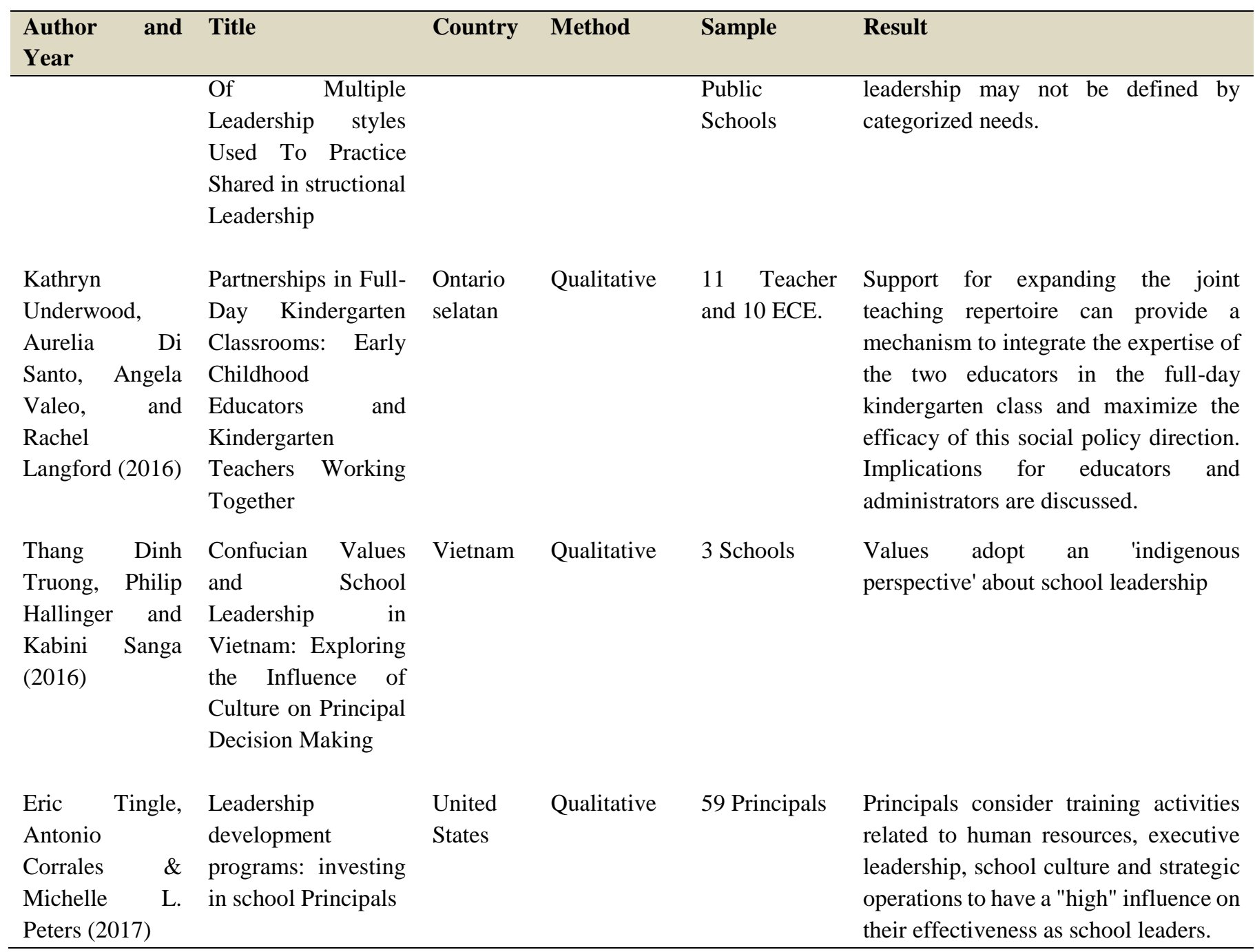

Research on principals' leadership and the implementation of full-day kindergarten in the world has been carried out in various countries. Table 1 shows that research has been carried out in schools, universities. The results of the majority of studies indicate that it is difficult to get literature that combines the two variables so that the writer will positively explain the findings for each variable. The results of research on the principal's leadership shows that the principal's leadership in carrying out his role as a leader has an impact on teacher performance and student achievement. The results of the full day kindergarten implementation study show that children who attend kindergarten (FDK) a full day experience academic and development benefits compared to children who attend a half-day program. However, research conducted by Michael A. Gottfried shows that children with disabilities in FDK have more days absent than children with disabilities in PDK. The broad conclusion is that when the authors consider all reviews of studies on principal leadership and the implementation of full-day kindergarten conducted in various countries in the world, showing that leadership and leadership style of the principal is very important for an organization including educational institutions and the application of full-day kindergarten has positive and negative impacts because of their influence on academics in the field of education.

The premise of this article is to find out how the principal's leadership is in implementing Fullday Kindergarten. Given the novelty of research on principals 'leadership in implementing Fullday Kindergarten, there has been no research exploring this relationship and the findings of this study are noteworthy, the importance of understanding principals' leadership in the implementation of full day kindergarten requires further discussion. The main finding of this article is that it is difficult to get literature that combines the two variables so that the writer will positively explain the findings for each variable. Findings related to the kindergarten fullday 


\section{International Journal of Current Science Research and Review}

ISSN: 2581-8341

Volume 04 Issue 03 March 2021

DOI: 10.47191/ijesrr/V4-i3-04, Impact Factor: 5.825

IJCSRR@ 2021

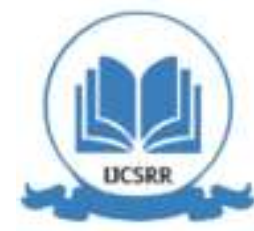

WWw.ijcsrr.org

education program that children in the FDK Program have a lower BMI, more outside play time and have a higher parent participation rate in fast training. Children in FDK programs are also less likely to watch television for a week than children in PDK programs. Findings made by Alexandra S. Youmans, John R. Kirby \& John G. Freeman show that no significant differences were found in children's reports regardless of the Program, children most enjoyed play activities, these findings reinforce the importance of kindergarten. Full day based child play program (Youmans, 2018. 105). Findings related to principals' leadership indicate that principals consider training activities related to human resources, executive leadership, school culture and strategic operations to have a "high" influence on their effectiveness as school leaders. This review has limitations including; first, the articles are reviewed only in English so other studies are not reviewed because of limitations. Second, dissertations and these are not discussed in this article because they can cause publication bias in the results. Third, the scope of the articles reviewed is still very limited, and it is very difficult to get literature that combines the two variables.

\section{CONCLUSION}

Principal's leadership is very important for the success of school organizations because the leader creates positive changes in education by encouraging existing staff in the school to take initiative and change. In implementing the Fullday Kindergarten education program, it is necessary for the principal to have the right leadership style to be able to carry out the Fullday Kindergarten program optimally. Potential learners can be influenced by the leadership of the principal in various ways through instructional and non-instructional tasks, the level and way of leadership of the school head affects student learning outcomes depending on certain behaviors and the overall features of the school environment namely the principal, teachers, students and community context. The results of most studies indicate that it is difficult to get literature that combines the two variables. Therefore, it is necessary to do a follow up related to the principal's leadership research in implementing full-day kindergarten.

\section{REFERENCES}

1. Ansari, A., \& Purtell, K. M. (2017). Activity settings in full-day kindergarten classrooms and children's early learning. Early childhood research quarterly, 38. doi:10.1016/j.ecresq.2016.09.003

2. Aravena, F. (2019). Destructive leadership behavior: An exploratory study in Chile. Leadership and Policy in Schools, 18(1). doi:10.1080/15700763.2017.1384501

3. Arifin, M. L., \& Zahro, U. C. (2018). Developing Full Day School Model Based On Multiple Intelligencesat Primary School Level. Paper presented at the 5th Asia Pasific Education Conference (AECON 2018).

4. Brianti, Y. A., Karini, S. M., \& Agustin, R. W. (2010). Perbedaan penyesuaian sosial pada anak yang menjalani sistem pembelajaran taman kanak-kanak full days dan reguler. WACANA, 2(2).

5. Brooks, M. C., \& Brooks, J. S. (2019). Culturally (ir) relevant school leadership: Ethno-religious conflict and school administration in the Philippines. International Journal of Leadership in Education, 22(1). doi:10.1080/13603124.2018.1503819

6. Brownell, M. D., Nickel, N. C., Chateau, D., Martens, P. J., Taylor, C., Crockett, L., . . . Goh, C. Y. (2015). Long-term benefits of full-day kindergarten: a longitudinal population-based study. Early child development and care, 185(2). doi:10.1080/03004430.2014.913586

7. Coughenour, C., Pharr, J., Gakh, M., Clark, S., \& Cheong, P. (2019). A Qualitative Study on Parental and Community Stakeholder Views of the Link between Full-Day Kindergarten and Health in Southern Nevada. Children, 6(2), 26. doi:10.3390/children6020026

8. Dou, D., Devos, G., \& Valcke, M. (2017). The relationships between school autonomy gap, principal leadership, teachers' job satisfaction and organizational commitment. Educational Management Administration \& Leadership, 45(6), 959-977. doi:10.1177/1741143216653975

9. Eisenschmidt, E., Kuusisto, E., Poom-Valickis, K., \& Tirri, K. (2019). Virtues that create purpose for ethical leadership: Exemplary principals from Estonia and Finland. Journal of Beliefs \& Values. doi:10.1080/13617672.2019.1618152

10. Fauziah, P. Y., \& Sugito, S. (2016). Pemetaan mutu PAUD full day untuk meningkatkan kualitas layanan dan kelembagaan Program PAUD. Jurnal Penelitian dan Evaluasi Pendidikan, 20(1). 


\section{International Journal of Current Science Research and Review}

ISSN: 2581-8341

Volume 04 Issue 03 March 2021

DOI: 10.47191/ijcsrr/V4-i3-04, Impact Factor: 5.825

IJCSRR@ 2021

Www.ijcsrr.org

11. Gottfried, M. (2018). Are Today's Students With Disabilities More Likely to Attend Full-Day Kindergarten or Part-Day Kindergarten? Analysis of Two Cohorts of Students and Their Teachers. Exceptional Children, 85(1), 28-45. doi:10.1177/0014402918782621

12. Gottfried, M. A. (2017). Does absenteeism differ for children with disabilities in full-day versus part-day kindergarten? Journal of Education for Students Placed at Risk (JESPAR), 22(4). doi:10.1080/10824669.2017.1388172

13. Gottfried, M. A., \& Le, V.-N. (2017). Is full-day kindergarten linked to children's physical activity? Early childhood research quarterly, 40. doi:10.1016/j.ecresq.2017.03.003

14. Gusman, H. E. (2020). Hubungan gaya kepemimpinan kepala sekolah dengan kinerja guru di SMP N Kecamatan Palembayan Kabupaten Agam. Jurnal Bahana Manajemen Pendidikan, 2(1), 293-301.

15. Hadi, Y. D. (2020). Kepemimpinan Visioner Kepala Sekolah Dalam Meningkatkan Mutu Pendidikan. Dinamika Penelitian: Media Komunikasi Penelitian Sosial Keagamaan, 19(2). doi:10.21274/dinamika.2019.19.2.

16. Hakim, S. N., \& Parameswari, A. (2015). Studi Komparasi Prestasi Belajar Siswa Kelas Satu Sekolah Dasar Program FullDay yang berasal dari Taman Kanak-Kanak Program Full-Day dan Reguler. Proseding seminarpsikologi \& kemanusiaan.

17. Hannum, E., \& Park, A. (2004). Children's educational engagement in rural China. In: Spencer Foundation.

18. Heagle, K., Timmons, K., Hargreaves, F., \& Pelletier, J. (2017). The social kindergartener: comparing children's perspectives of full-and half-day kindergarten. Early child development and care, 187(5-6). doi:10.1080/03004430.2016.1199551

19. Heydon, R., Moffatt, L., \& Iannacci, L. (2015). 'Every day he has a dream to tell': classroom literacy curriculum in a fullday kindergarten. Journal of Curriculum Studies, 47(2).

20. Irayasa, K., Maddatuang, M., Suprapta, S., Farid, A. M., Alfian, I., \& Rahman, R. (2019). Kajian Sistem Sekolah Sehari Penuh (Full Day School) Di Sman 11 Makassar. Jurnal Nalar Pendidikan, 7(1), 1-10.

21. Jones, M., Adams, D., Hwee Joo, M. T., Muniandy, V., Perera, C. J., \& Harris, A. (2015). Contemporary challenges and changes: principals' leadership practices in Malaysia. Asia Pacific Journal of Education, 35(3). doi:10.1080/02188791.2015.1056591

22. Joseph, G., Soderberg, J. S., Stull, S., Cummings, K., McCutchen, D., \& Han, R. J. (2019). Inter-Rater Reliability of Washington State's Kindergarten Entry Assessment. Early Education and Development. doi:10.1080/10409289.2019.1674589

23. Langford, R., Di Santo, A., Valeo, A., Underwood, K., \& Lenis, A. (2018). The innovation of Ontario full-day kindergarten educator teams: have they reproduced the split systems of care and education? Gender and Education, 30(5), 569-586. doi:10.1080/09540253.2016.1258456

24. Leithwood, K., Harris, A., \& Hopkins, D. (2019). Seven strong claims about successful school leadership revisited. School Leadership \& Management. doi:10.1080/13632434.2019.1596077

25. Lijuan, L., Hallinger, P., \& Ko, J. (2016). Principal leadership and school capacity effects on teacher learning in Hong Kong. International Journal of Educational Management, 30(1). doi:10.1108/IJEM-03-2014-0035

26. Marlina, N. (2020). Persepsi guru tentang gaya kepemimpinan kepala sekolah di sekolah menengah kejuruan (SMK) negeri kabupaten Sijunjung. Jurnal Bahana Manajemen Pendidikan, 1(1). doi:10.23036/bmp.v1i1.2689

27. Muflikha, M., \& Haryanto, B. (2019). Strategi Manajemen Kepemimpinan Kepala Sekolah dalam Meningkatkan Kualitas Kinerja Pendidik dan Tenaga Kependidikan. PALAPA, 7(2), 309-323.

28. Pyle, A., Prioletta, J., \& Poliszczuk, D. (2018). The play-literacy interface in full-day kindergarten classrooms. Journal Early Childhood Education, 46(1). doi:10.1007/s10643-017-0852-z.

29. Quin, J., Deris, A., Bischoff, G., \& Johnson, J. T. (2015). Comparison of Transformational Leadership Practices: Implications for School Districts and Principal Preparation Programs. Journal of Leadership Education, 14(3). doi:1012806/V14/I3/R5

30. Setiyati, S. (2014). Pengaruh kepemimpinan kepala sekolah, motivasi Kerja, dan budaya sekolah terhadap kinerja guru. Jurnal Pendidikan Teknologi dan Kejuruan, 22(2). doi:10.21831/jptk.v22i2.8931

31. Shoval, E., Sharir, T., Arnon, M., \& Tenenbaum, G. (2018). The effect of integrating movement into the learning environment of kindergarten children on their academic achievements. Journal Early Childhood Education, 46(3). doi:10.1007/s10643017-0870-x 


\section{International Journal of Current Science Research and Review}

ISSN: 2581-8341

Volume 04 Issue 03 March 2021

DOI: 10.47191/ijesrr/V4-i3-04, Impact Factor: 5.825

IJCSRR@ 2021

WwW.ijcsrr.org

32. Thompson, J. A., \& Sonnenschein, S. (2016). Full-day kindergarten and children's later reading: The role of early word reading. Journal of Applied Developmental Psychology, 42. doi:10.1016/j.appdev.2015.11.005

33. Timmons, K. (2018). Educator expectations in full-day Kindergarten: Comparing the factors that contribute to the formation of early childhood educator and teacher expectations. Journal Early Childhood Education, 46(6). doi:10.1007/s10643-0180891-0

34. Tingle, E., Corrales, A., \& Peters, M. L. (2019). Leadership development programs: Investing in school principals. Educational Studies, 45(1). doi:10.1080/03055698.2017.1382332

35. Truong, T. D., Hallinger, P., \& Sanga, K. (2017). Confucian values and school leadership in Vietnam: Exploring the influence of culture on principal decision making. Educational Management Administration \& Leadership, 45(1). doi:10.1177/1741143215607877

36. Underwood, K., Di Santo, A., Valeo, A., \& Langford, R. (2016). Partnerships in full-day kindergarten classrooms: Early childhood educators and kindergarten teachers working together. Journal of Childhood Studies, 41(1). doi:10.18357/jcs.v41i1.15696

37. Urick, A. (2016). Examining US principal perception of multiple leadership styles used to practice shared instructional leadership. Journal of Educational Administration, 54(2). doi:10.1108/JEA-07-2014-0088

38. Youmans, A. S., Kirby, J. R., \& Freeman, J. G. (2018). How effectively does the full-day, play-based kindergarten programme in Ontario promote self-regulation, literacy, and numeracy? Early child development and care, 188(12). doi:10.1080/03004430.2017.1287177

Cite this Article: Nanik Lestari, Dini Cahyati (2021). The Principal's Leadership in Implementing the Full-Day Kindergarten: A Literature Review. International Journal of Current Science Research and Review, 4(3), 164-174 